\title{
Adherence to antiretroviral therapy and the associated factors among people living with HIV/AIDS in Northern Peru: a cross-sectional study
}

\author{
Juan M. Leyva-Moral 1,2,3, Blanca K. Loayza-Enriquez ${ }^{4,5}$, Patrick A. Palmieri2,6,7,8* ${ }^{*}$, Genesis M. Guevara-Vasquez ${ }^{4,7}$, \\ Ursula E. Elias-Bravo ${ }^{9}$, Joan E. Edwards ${ }^{10}$, María Feijoo-Cid ${ }^{1}$, Lucy Y. Davila-Olano ${ }^{11}$, Juan R. Rodriguez-Llanos ${ }^{12}$ \\ and Franco E. Leon-Jimenez ${ }^{13,14}$
}

\begin{abstract}
Background: There are approximately 72,000 people living with HIV/AIDS (PLHIV) in Peru. Non-adherence to antiretroviral therapy (ART) is the most important factor for therapeutic failure and the development of resistance. Peru has achieved moderate progress in meeting the $90-90-90$ targets, but only $60 \%$ of PLHIV receiving ART are virally suppressed. The purpose of this study was to understand ART adherence in the Peruvian context, including developing sociodemographic and clinical profiles, evaluating the clinical management strategies, and analyzing the relationships between the variables and adherence of PLHIV managed at a regional HIV clinic in Lambayeque Province (Northern Peru).

Methods: This was a cross-sectional study with 180 PLHIV adults, non-randomly but consecutively selected with selfreported ART compliance (78.2\% of the eligible population). The PLHIV profile (PLHIV-Pro) and the Simplified Medication Adherence Questionnaire (SMAQ) were used to collect sociodemographic information, clinical variables, and data specific to ART adherence. Descriptive analysis of sociodemographic and clinical characteristics was performed. Bivariate analysis was performed with the Mann-Whitney test, Chi square test, and Yates correction.

Results: The 180 PLHIV sample included $78.9 \%$ men, 49.4\% heterosexual, 45\% with a detectable HIV-1 viral load less than 40 copies $/ \mathrm{ml}, 58.3 \%$ not consistently adherent, and only $26.1 \%$ receiving Tenofovir + Lamivudine + Efavirenz. Risk factors significant for non-adherence included concurrent tuberculosis, discomfort with the ART regime, and previous pauses in ART. Multivariate analysis of nested models indicated having children is a protector factor for adherence.

Conclusions: Self-reported adherence appeared to be low and the use of first-line therapy is not being prescribed homogeneously. Factors associated with nonadherence are both medical and behavioral, such as having tuberculosis, pausing ART, or experiencing discomfort with ART. The Peruvian government needs to update national technical standards, monitor medication availability, and provide education to health care professionals in alignment with evidence-based guidelines and international recommendations. Instruments to measure adherence need to be developed and evaluated for use in Latin America.
\end{abstract}

\footnotetext{
*Correspondence: Patrick.Palmieri@globalnursing.org

${ }^{2}$ Center for Health Sciences Research, Universidad María Auxiliadora, Av.

Canto Bello 431, San Juan de Lurigancho, Lima, Lima 15408, Peru

Full list of author information is available at the end of the article
} 
Keywords: HIV: Human Immunodeficiency Virus, AIDS: Acquired Immune Deficiency Syndrome, ART: Antiretroviral therapy, Adherence, SMAQ: Simplified Medication Adherence Questionnaire, Peru, PLHIV: People living with HIV, Compliance

\section{Introduction}

At the end of 2017, there were approximately 2 million [1.5-2.3 million] people living with HIV (PLHIV) in Latin America $[1,2]$. In Peru, there are approximately 72,000 [55,000-94,000] PLHIV; however, an estimated 16,250 of these people are unaware of their infection [3]. HIV accounts for $1.8 \%$ of the total disease burden and $1.9 \%$ of the total annual [2.200] deaths in Peru [4]. Each year, an additional 2700 HIV infections are diagnosed, with $97 \%$ related to sexual transmission and men representing 8 of 10 cases [3]. Men who have sex with men (MSM) and transgender women (TW) in Peru are disproportionately impacted by HIV [5], with a prevalence as high as $12.4 \%$ for MSM and 30\% for TW compared to less than $0.23 \%$ for the general population [6, 7]. In addition, MSM and TW account for about $60 \%$ of new infections [8]. However, the majority of the HIV literature for these populations in Peru is based on international surveillance or small observational studies focused on the Lima Metropolitan region [7-12]. As such, the number of MSM and TW impacted by HIV/AIDS is largely unknown.

The HIV prevalence worldwide is $1.2 \%$, with the largest prevalence (9.0\%) reported in sub-Saharan Africa [13, 14]. The HIV prevalence has incrementally increased from $0.2 \%$ to $0.9 \%$ in Latin America $[15,16]$ while the prevalence in Peru remains between $0.4 \%$ to $0.5 \%$ [17]. From 2010 to 2015; however, new HIV infections in Peru increased by $24 \%$ and AIDS-related deaths increased by $14 \%$ [18], yet across the region there was only a $3 \%$ increase [19]. This trend is attributed to already infected people being diagnosed with increased screenings, problems with late diagnosis, increased heterosexual diagnosis, and HIV + people living longer with ART [20].

Although HIV can be effectively managed with ART as a chronic condition [21] rather than a terminal illness [22], the call by the Joint United Nations Programme on HIV/AIDS (UNAIDS) to enhance ART access in developing economies, such as Peru, was necessary to move governments into action [23]. The Peruvian Ministry of Health, or Ministerio de Salud del Perú (MINSA), directs HIV care through a series of national regulations and guidelines [24-27]. This direction resulted in HIV testing with pretest counseling and signed informed consents except for pregnancy, and blood and organ donation [25]. HIV testing is only free for people with public health insurance [28].

Since 2004, ART has been offered without cost in all regions of Peru [29] through 145 facilities [3]. In 2017, approximately 47,762 PLHIV received ART in Peru, more than double from 2000, resulting in the reduction of AIDS related mortality from 7.3 to 3.9 per 100,000 people from 2000 to 2013 [3, 30]. Overall, Peru has achieved moderate progress in achieving the 90-90-90 targets for 2020 [31] as an estimated 60\% $(43,000)$ of PLHIV know their status, $60 \%(43,000)$ are receiving ART, and $60 \%(24,000)$ in treatment are virally suppressed [5, 32]. Importantly, target measurement is largely based on estimates as there is not a national monitoring system [33].

\section{Objective}

Despite the ART scale-up in Peru, including more resources dedicated to HIV management in an economically constrained health sector, surprisingly few studies focused on ART adherence have been published from Peru [11, 34-40] with none conducted outside the Lima Metropolitan region. Yet, ART adherence is problematic as the facilitators and barriers in Peru are not well understood [34]. The lack of reliable data from most Latin American countries regarding diagnosis, management, and outcomes makes it difficult to implement targeted interventions [1]. As such, the purpose of this study was to understand the current state of ART adherence for PLHIV managed at the regional HIV clinic located in Northern Peru, (Chiclayo, Lambayeque). The study sought to describe the sociodemographic profile of PLHIV, to determine the relationships between sociodemographic variables and ART adherence, and to identify the clinical management compliance with international evidence-based guidelines and recommendations.

This study contributes to the limited South American knowledge about ART adherence outside major metropolitan areas and fills a gap in the Peruvian literature about ART adherence in areas outside of Lima [41]. As there are neither regional nor national registries in Peru specific to ART adherence, data for this study was manually collected through chart reviews and participant interviews. This study is the first reliable source of data specific to PLHIV living in the Peruvian provinces and ART adherence.

\section{Methods \\ Study design and population}

This was an observational study with a cross-sectional design [42]. Since the proportion of the ART adherent population is unknown, a non-probabilistic consecutive sampling strategy $[43,44]$ was implemented in the 
fall of 2017. From the 230 adult HIV patients managed with ART at the regional HIV clinic in Lambayeque, 180 (78.3\%) agreed to participate in this study. The study was approved by the regional health system ethics committee (Protocol 0223-024-16). All participants signed an informed consent prior to entering the study. In addition to the consent document, researchers explained the purpose of the study, including the objectives, risks, benefits, and other ethical aspects. Participants received no financial compensation and they were able to voluntarily leave the study at any time.

\section{Instruments and measures}

The data were collected using two instruments: A selfdeveloped PLHIV profile (PLHIV-Pro) and the Simplified Medication Adherence Questionnaire (SMAQ). The 36-item closed-ended PLHIV-Pro was developed from the available evidence specific to sociodemographic and clinical variables associated with ART adherence and engagement in clinical management. The profile was validated through an external expert review (two nurses and two physicians specialized in HIV care, one patient, and one clinical professor with HIV management experience) and a pilot test was completed with 10 patients to evaluate item comprehension, cultural applicability, and social acceptance. The Simplified Medication Adherence Questionnaire (SMAQ) has 6-tiems, reported to be reliable and valid with a $0.75 \alpha$-Cronbach, $82 \%$ general interobserver agreement, $72 \%$ sensitivity, and $91 \%$ specificity [45]. The instrument was piloted with 10 patients; these results were excluded from analysis. The time to complete the instruments was 10 to $15 \mathrm{~min}$. The two instruments were administered by four researchers (nurses and midwives) to participants following their scheduled health consultation in a private examination room. To avoid bias, data available in the medical record, such as comorbidities, opportunistic infections, viral load, CD4 levels, place of diagnosis, and year of diagnosis, were verified with participant permission.

\section{Data analysis}

Data were analyzed using SPSS v22.0 [46] and EPIDAT v3.1 [47] statistical software packages. First, Kolmogorov-Smirnov normality tests were performed to recognize non-parametric variables [48]. Then, descriptive analysis was used for the qualitative variables, including frequency distribution, and central tendency and dispersion measures were used for the quantitative variables [49]. Next, associations were explore between the participant characteristics and their ART adherence with the Mann-Whitney test [50]. In addition, bivariate analysis of qualitative variables was completed using the Chi square test, Yates correction, and linear tendency (for ordinal variables), with prevalence ratios to calculate associations [51]. Finally, multivariate analysis was conducted using a binomial linear model nested type [52] considering those variables with p-values up to 0.20 . A significant "p" value lower than $5 \%$ and a confidence interval of $95 \%$ of the corresponding statistic was acceptable.

\section{STROBE compliance}

This study is reported in compliance with the STROBE (Strengthening The Reporting of OBservational Studies in Epidemiology) statement [53] (von Elm et al., 2007) specific to the minimum reporting requirements as stated in the cross-sectional study checklist [54].

\section{Results}

The study sample included 180 PLHIV, mostly men (80\%; 140 ) with a median age of 30 years (inter-quartile range of 24 to 38.5 years). Almost half of the participants selfidentified as heterosexuals $(49.4 \%$; 89$)$ and single $(67.8 \%$; $122)$ with no children $(63.9 \% ; 115)$, and $(19.4 \% ; 35)$, living with a partner, including about half of them living with a same sex partner $(11.1 \%$; 20$)$. About half the participants were diagnosed with HIV in a hospital (52.8\%; 95), with the sexual route the most prevalent cause $(46.7 \%$; 84 homosexual). Participants primarily lived in urban areas (75.6\%; 136), completed university studies $(39.4 \%, 71)$, and worked self-employed (40\%; 72) with a median family monthly income of 1000 soles, or about $\$ 330$ (interquartile range of 625 to 1500 soles). A summary of the relevant socio-demographic and ART adherence characteristics are provided in Table 1. Also, the complete data are available in the Additional file 1: Table S1.

The median time living with a diagnosis of HIV was 2 years (IQR $1-3)$, with most participants $(75 \%$; 135$)$ starting ART within 1 year (mean 2 years; IQR $1-5$ ). Only 21.7\% (39) of the participants were ART-naive (mean 1 year; IQR 1-2). For the ART, the most frequent drug combination was Zidovudine + Lamivudine + Efavirenz (34.4\%; 62). More than half of the participants (55\%; 99) had an undetectable HIV-1 viral load ( $\leq 40$ copies $/ \mathrm{ml}$ ), and $63.3 \%$ (114) had CD4 monitoring $\geq 300 \mathrm{cel} / \mu \mathrm{L}$ (mean 356; IQR 261-527 cel/ $\mu \mathrm{L})$.

Many participants (108) reported comorbidities, depression was the most prevalent $(42.2 \%$; 76). Among participants diagnosed with a sexually transmitted infection $(30 \% ; 54)$, syphilis was the most frequent $(12.8 \%$; 23$)$. Most participants shared their HIV diagnosis with a family member $(79.4 \% ; 143)$, primarily because they wanted emotional support managing the treatment (64.3\%; 92). Among those who did not share their HIV diagnosis with their family $(19.4 \%$; 35$)$ the main reason was fear of rejection, personal shame, and lack of confidence $(32.4 \%$; $12)$, or not wanting to cause more problems $(32.4 \% ; 12)$. 
Table 1 Summary of socio-demographic characteristics of PLHIV and ART adherence at the HIV clinic (2016-2017)

\begin{tabular}{|c|c|c|c|c|}
\hline Variable & $\mathrm{N}(\%)$ & Non-adherence/total (\%) & PR [Cl 95\%] & $p$ value \\
\hline $\operatorname{Age}^{* *}$ & $30[24-38.50]$ & 29 [24-39] & & 0.646 \\
\hline \multicolumn{5}{|l|}{ Sex } \\
\hline Male & $144(80.0)$ & $81 / 144(56.3)$ & & \\
\hline Female & $36(20.0)$ & $24 / 36(66.7)$ & $0.84[0.64-1.11]$ & 0.257 \\
\hline \multicolumn{5}{|l|}{ Sexual orientation } \\
\hline Homosexual & $63(35.0)$ & 35/63 (55.6) & & 0.853 \\
\hline Heterosexual & $89(49.4)$ & $53 / 89(59.6)$ & $1.07[0.81-1.42]$ & \\
\hline Bisexual & $28(15.6)$ & $17 / 28(60.7)$ & $1.09[0.75-1.58]$ & \\
\hline \multicolumn{5}{|l|}{ Marital status } \\
\hline Single & $122(67.8)$ & $68 / 122(55.7)$ & & 0.778 \\
\hline Living with someone/partner & 35 (19.4) & $22 / 35(62.9)$ & $1.13[0.84-1.52]$ & \\
\hline Married & $12(6.7)$ & $8 / 12(66.7)$ & $1.20[0.78-1.84]$ & \\
\hline Divorced/widowed & $11(6.1)$ & $7 / 11(63.6)$ & $1.14[0.71-1.83]$ & \\
\hline \multicolumn{5}{|l|}{ Number of children } \\
\hline 0 & $115(63.9)$ & $60 / 115(52.2)$ & & $0.029^{*}$ \\
\hline 1 & $21(11.7)$ & $13 / 21(61.9)$ & $1.19[0.81-1.73]$ & \\
\hline 2 & $25(13.9)$ & 19/25 (76) & $1.46[1.10-1.93]$ & \\
\hline$\geq 3$ & 19 (10.6) & $13 / 19(68.4)$ & $1.31[0.92-1.86]$ & \\
\hline Monthly family incomes** & $1000[625-1500]$ & 1000 [700-1800] & & 0.302 \\
\hline \multicolumn{5}{|l|}{ ART prescription } \\
\hline $\mathrm{ZDV}+3 \mathrm{TC}+\mathrm{EFV}$ & $62(34.4)$ & $39 / 62(62.9)$ & & 0.861 \\
\hline $\mathrm{TDF}+3 \mathrm{TC}+\mathrm{EFV}$ & $47(26.1)$ & $25 / 47(53.2)$ & $0.85[0.61-1.18]$ & \\
\hline$A B C+3 T C+E F V$ & $26(14.4)$ & 14/26 (53.8) & $0.86[0.57-1.28]$ & \\
\hline $\mathrm{TDF}+3 \mathrm{TC}+\mathrm{ATV}+\mathrm{RTV}$ & $15(8.3)$ & $9 / 15(60)$ & $0.95[0.61-1.50]$ & \\
\hline Other & $30(16.7)$ & $18 / 30(60)$ & $0.95[0.67-1.35]$ & \\
\hline \multicolumn{5}{|l|}{ Place of diagnosis } \\
\hline Hospital & $95(52.8)$ & $60 / 95(63.2)$ & & $0.035^{*}$ \\
\hline Primary Health Center & $59(32.8)$ & $32 / 59(54.2)$ & $0.86[0.65-1.14]$ & \\
\hline Private lab or clinic & $16(8.9)$ & $5 / 16(31.3)$ & $0.49[0.24-1.04]$ & \\
\hline Ambulatory care & $10(5.6)$ & $8 / 10(80)$ & $1.27[0.90-1.79]$ & \\
\hline Viral Load & & & & 0.513 \\
\hline$>40$ & $81(45.0)$ & $51 / 81(63)$ & & 0.255 \\
\hline$\leq 40$ & $99(55.0)$ & $54 / 99(54.5)$ & $1.15[0.90-1.48]$ & \\
\hline Nivel de CD4** & $356[261-527]$ & $362[264-516]$ & & 0.879 \\
\hline$\leq 300$ & $66(36.7)$ & $37 / 66(56.1)$ & & 0.638 \\
\hline$>300$ & $114(63.3)$ & $68 / 114(59.6)$ & $0.94[0.72-1.22]$ & \\
\hline Years with no ART since diagnosis** & $2[1-5]$ & $2[1-5]$ & & 0.662 \\
\hline$\geq 1$ & $45(25)$ & 26/45 (57.8) & & 0.930 \\
\hline$<1$ & $135(75)$ & $79 / 135$ (58.5) & $0.99[0.74-1.32]$ & \\
\hline Years living with $\mathrm{HIV} \mathrm{V}^{* *}$ & $2[1-3]$ & $2[1-3]$ & & 0.980 \\
\hline$\geq 1$ & 141 (78.3) & $86 / 141(61)$ & & 0.169 \\
\hline$<1$ & $39(21.7)$ & 19/39 (48.7) & $1.25[0.88-1.77]$ & \\
\hline Years taking $A R T^{* *}$ & $1[1,2]$ & $1[1,2]$ & & 0.988 \\
\hline$\geq 1$ & $122(67.8)$ & 73/122 (59.8) & & 0.553 \\
\hline$<1$ & $58(32.2)$ & $32 / 58(55.2)$ & $1.08[0.82-1.43]$ & \\
\hline \multicolumn{5}{|l|}{ Opportunistic infection } \\
\hline Yes & $80(44.4)$ & 43/80 (53.8) & & 0.265 \\
\hline No & $100(55.6)$ & $62 / 100(62)$ & $0.87[0.67-1.12]$ & \\
\hline
\end{tabular}


Table 1 (continued)

\begin{tabular}{|c|c|c|c|c|}
\hline Variable & $\mathrm{N}(\%)$ & Non-adherence/total (\%) & PR [Cl 95\%] & $p$ value \\
\hline \multicolumn{5}{|l|}{ Pulmonary tuberculosis } \\
\hline Yes & $18(10.0)$ & $6 / 18(33.3)$ & & $0.023^{*}$ \\
\hline No & $162(90.0)$ & $99 / 162(61.1)$ & $0.55[0.28-1.06]$ & \\
\hline \multicolumn{5}{|l|}{ Side effects with actual ART prescription } \\
\hline Yes & $92(51.1)$ & $62 / 92(67.4)$ & & $0.012^{*}$ \\
\hline No & $88(48.9)$ & 43/88 (48.9) & $1.38[1.07-1.78]$ & \\
\hline \multicolumn{5}{|l|}{ Action taken with side effects } \\
\hline Ask for medical advice & $57(62.0)$ & $38 / 57(66.7)$ & & $0.031^{*}$ \\
\hline Wait it to stop & $28(30.4)$ & $22 / 28(78.6)$ & $1.18[0.90-1.54]$ & \\
\hline Keep taking my ART & $4(4.3)$ & $2 / 4(50)$ & $0.75[0.28-2.03]$ & \\
\hline Did not answer & $3(3.3)$ & $0 / 3(0)$ & - & \\
\hline \multicolumn{5}{|l|}{ ART abandoned at anytime } \\
\hline Yes & $83(46.1)$ & $72 / 83(86.7)$ & & $0.001^{*}$ \\
\hline No & $97(53.9)$ & $33 / 97(34)$ & $2.55[1.91-3.41]$ & \\
\hline \multicolumn{5}{|l|}{ Length of ART abandon } \\
\hline$>30$ days & $15(18.1)$ & $9 / 15(60)$ & & $0.001^{*}$ \\
\hline 10-30 days & $16(19.3)$ & $14 / 16(87.5)$ & $1.46[0.93-2.29]$ & \\
\hline 1-9 days & $52(62.7)$ & $49 / 52(94.2)$ & $1.57[1.03-2.39]$ & \\
\hline \multicolumn{5}{|l|}{ Reason for abandonment } \\
\hline $\begin{array}{l}\text { Forgetfulness or neglect when attending a } \\
\text { commitment, meeting or work }\end{array}$ & $35(40.7)$ & $35 / 35(100)$ & & $0.033^{*}$ \\
\hline Bureaucracy to get access to ART & $17(19.8)$ & $13 / 17(76.5)$ & $0.76[0.59-1.00]$ & \\
\hline Lack of privacy or feeling better & $11(12.8)$ & 9/11 (81.8) & $0.82[0.62-1.08]$ & \\
\hline Fear of side effects & $8(9.3)$ & $6 / 8(75)$ & $0.75[0.50-1.12]$ & \\
\hline Others & 15 (17.4) & $11 / 15(73.3)$ & $0.73[0.54-1.00]$ & \\
\hline
\end{tabular}

Zidovudine $=$ ZDV; Lamivudine $=3 \mathrm{TC}$; Efavirenz $=\mathrm{EFV}$; Tenofovir $=\mathrm{TDF}$; Abacavir $=\mathrm{ABC}$; Atazanavir $=\mathrm{ATV}$; Ritonavir $=\mathrm{RTV}$; Lopinavir $=\mathrm{LPV} ; \mathrm{PR}=$ prevalence ratio ${ }^{*}$ p-value $<0.05 * *$ Mean $[$ IQR]

A high percentage of participants reported satisfaction with the care they received from their physician $(90 \%$; $162)$ and higher satisfaction with the nursing care $(97.2 \%$; 175).

In terms of ART adherence, 58.3\% (105) of the participants were not adherent, with $43.3 \%$ (78) sometimes forgetting to take their ART. In this regard, about half stopped their ART regime at some point (46.1\%; 83), in most of these cases up to 9 days $(62.7 \%$; 52$)$, with the main cause being "forgetfulness or neglect when attending a commitment, meeting, or work" (40.7\%; 35). During the last month prior to this study, only $10 \%$ (18) of participants forgot their ART doses for 1-2 days, and another 5.6\% (10) stopped taking their ART as they felt sick. More than half of the participants had side effects with their current ART regime (51.1\%; 92), including heartburn/stomach pain $(13.3 \% ; 24)$ and skin rash $(11.7 \%$; $21)$ as the most frequent. Some participants $(22.2 \% ; 40)$ also acknowledged at least moderate alcohol consumption (Table 2).

The bivariate analysis indicated participant discomfort with the treatment regime $(\mathrm{p}=0.012$; $\mathrm{RP}=1.38$; IC 95\%
$1.07-1.78)$; stopping treatment at any time $(\mathrm{p}<0.001$; $\mathrm{RP}=2.55$; IC 95\%:1.91-3.41) and stopping treatment for up to 9 days $(\mathrm{p}=0.001$; $\mathrm{RP}=1.57$; IC $95 \%: 1.03-2.39$ ) were significant risk factors for non-adherence (Table 3). Other risk factors for non-adherence included concurrent TBC ( $\mathrm{p}=0.013$; $\mathrm{RP}=5.19$; IC 95\%:1.42-18.91), feeling sick during the ART regime $(\mathrm{p}=0.012 ; \mathrm{RP}=2.73$; IC 95\%:1.24-6.00), and stopping ART at some point $(\mathrm{p}<0.001 ; \mathrm{RP}=17.17 ;$ IC 95\%:7.19-41). In addition, multivariate analysis of nested models indicated having children could be a significant protective factor for adherence $(\mathrm{p}=0.024 ; \mathrm{RP}=0.25$; IC 95\%:0.08-0.84).

\section{Discussion}

The participants in this study were mostly young (24.0 to 38.5 years) men $(80 \%$; 144$)$. The socioeconomic data from this study is similar to the national data [18] and data reported by other countries in the region such as Colombia [55], reflecting a globalized reality that HIV adversely impacts young men. Participants in this study were mostly self-identified as heterosexual $(49.4 \%$; 89$)$ and homosexual $(35 \%$; 63$)$. These figures are similar to 
Table 2 Adherence characteristics of people receiving ART at the HIV Clinic (2016-2017)

\begin{tabular}{|c|c|c|c|}
\hline Variable & Category & $\mathbf{n}$ & $\%$ \\
\hline \multirow[t]{2}{*}{ Adherence $\geq 90 \%$} & Yes & 75 & 41.7 \\
\hline & No & 105 & 58.3 \\
\hline \multirow[t]{3}{*}{ Did you ever forget to take your medication? } & Yes & 78 & 43.3 \\
\hline & No & 99 & 55.0 \\
\hline & Did not answer & 3 & 1.7 \\
\hline \multirow[t]{3}{*}{ I always take my medication at the indicated time } & Yes & 130 & 72.2 \\
\hline & No & 46 & 25.6 \\
\hline & Did not answer & 4 & 2.2 \\
\hline \multirow[t]{3}{*}{ I stop taking my medication when I feel sick } & Yes & 10 & 5.6 \\
\hline & No & 164 & 91.1 \\
\hline & Did not answer & 6 & 3.3 \\
\hline \multirow[t]{3}{*}{ I forget to take my medication on the weekends } & Yes & 8 & 4.4 \\
\hline & No & 166 & 92.2 \\
\hline & Did not answer & 6 & 3.3 \\
\hline \multirow[t]{5}{*}{ Number of days I forgot to take my medication in the last week } & None & 156 & 86.7 \\
\hline & 1 day & 17 & 9.4 \\
\hline & $2-3$ days & 2 & 1.1 \\
\hline & $4-5$ days & 2 & 1.1 \\
\hline & $>5$ days & 3 & 1.7 \\
\hline \multirow[t]{5}{*}{ Number of days I forgot to take my medication in the last month } & None & 149 & 82.8 \\
\hline & $1-2$ days & 18 & 10.0 \\
\hline & $3-5$ days & 4 & 2.2 \\
\hline & $6-10$ days & 6 & 3.3 \\
\hline & Did not answer & 3 & 1.7 \\
\hline
\end{tabular}

the United Kingdom where, in 2011, heterosexual infections accounted for $49 \%$ of all adult 5423 diagnoses [56]. Contrarily, in other countries, such as Spain [57] and the United States [58] only about $25 \%$ were identified as heterosexual, with the highest number of diagnoses (53.6\%) in MSM. The difference in our study could be explained by the pervasive discrimination experienced by Lesbian, Gay, Transgender, and Bisexual people in Latin America [59]. For example, more than $45 \%$ of Peruvian adult women surveyed would not buy vegetables from a shopkeeper known to be living with HIV [2]. This type of discrimination might influence participant responses to some of the questions.

\section{Adequacy of clinical management}

Regarding ART clinical management, the World Health Organization [60] states, "ART should be started in all adults living with HIV, regardless of WHO clinical stage and at any CD4 cell count" (p. xxxi). Early ART initiation is associated with decreased new infections [61]. However, the technical standard published by the Peruvian government [27] specify ART based on different criteria (Table 4). In addition, the World Health Organization [60] recommendation, and the Peruvian government [27], indicate the combination of Tenofovir + Lamivudine + Efavirenz is the first choice for ART; however, only $26 \%$ of the participants in this study received this combination. Yet, more participants, $34.4 \%$ received the less effective alternative treatment [60], Zidovudine + Lamivudine + Efavirenz. During the data collection process for this study, clinicians and participants indicated the recommended ART medications were not routinely available in the region. Despite published information that the WHO recommended ART is widely available in Peru, local HIV experts suggested the provinces routinely lack Lamivudine and/ or Tenofovir. This demonstrates the reality reported in literature for Metropolitan Lima may differ from the experiences in the provinces.

Also, each PLHIV presenting at the regional clinic is initially evaluated by a psychologist. In the presence of a suspected mental condition, a PLHIV is required to be referred to a psychiatrist for diagnosis and clinical management. Similar to other studies [62-65] most participants in this study had a depression diagnosis. This is the first study to report depression as a problem for PLHIV in Peru. Importantly, the local experts reported the initial psychological evaluations are completed in a timely 
Table 3 Multivariate analysis of sociodemographic characteristics and ART adherence for people managed at the HIV clinic (2016-2017)

\begin{tabular}{|c|c|c|c|c|}
\hline \multirow[t]{2}{*}{ Variable } & \multicolumn{2}{|l|}{ Bivariate } & \multicolumn{2}{|l|}{ Multivariate } \\
\hline & RP [IC 95\%] & p-valor & RP [IC 95\%] & p-valor \\
\hline \multicolumn{5}{|l|}{ Number of children } \\
\hline None & & $0.029^{*}$ & & $0.024^{*}$ \\
\hline 1 & $1.19[0.81-1.73]$ & & $0.25[0.08-0.84]$ & \\
\hline 2 & $1.46[1.10-1.93]$ & & $0.24[0.07-0.83]$ & \\
\hline$\geq 3$ & $1.31[0.92-1.86]$ & & $0.21[0.06-0.77]$ & \\
\hline \multicolumn{5}{|l|}{ Place of diagnosis } \\
\hline Hospital & & $0.045^{*}$ & & \\
\hline Primary Care Center & $0.86[0.65-1.14]$ & & & \\
\hline Private lab or clinic & $0.49[0.24-1.04]$ & & & \\
\hline Ambulatory care & $1.27[0.90-1.79]$ & & & \\
\hline \multicolumn{5}{|l|}{ TBC } \\
\hline Yes & & $0.023^{*}$ & & $0.013^{*}$ \\
\hline No & $0.55[0.28-1.06]$ & & $5.19[1.42-18.91]$ & \\
\hline \multicolumn{5}{|l|}{ Complaints about the current ART regime } \\
\hline Yes & & $0.012^{*}$ & & $0.012^{*}$ \\
\hline No & $1.38[1.07-1.78]$ & & $2.73[1.24-6.00]$ & \\
\hline \multicolumn{5}{|l|}{ Action taken when experiencing side effects } \\
\hline Visit the physician & & $0.041^{*}$ & & \\
\hline Nothing. just wait it to stop & $1.18[0.90-1.54]$ & & & \\
\hline Take my ART anyway & $0.75[0.28-2.03]$ & & & \\
\hline Did not answer & - & & & \\
\hline \multicolumn{5}{|l|}{ ART cessation ever } \\
\hline Yes & & $p<0.001^{*}$ & & $\mathrm{p}<0.001^{*}$ \\
\hline No & $2.55[1.91-3.41]$ & & $17.17[7.19-41]$ & \\
\hline \multicolumn{5}{|l|}{ Length of last ART cessation } \\
\hline$>30$ days & & $0.001^{*}$ & & \\
\hline 10-30 days & $1.46[0.93-2.29]$ & & & \\
\hline $1-9$ days & $1.57[1.03-2.39]$ & & & \\
\hline \multicolumn{5}{|l|}{ Reason for cessation ART } \\
\hline $\begin{array}{l}\text { Forgetfulness or neglect when attending a commitment. meet- } \\
\text { ing or work }\end{array}$ & & $0.033^{*}$ & & \\
\hline Permissions. paperwork for getting access to ART & $0.76[0.59-1.00]$ & & & \\
\hline My own decision. lack of privacy or wanting to feel better & $0.82[0.62-1.08]$ & & & \\
\hline Fear of side effects & $0.75[0.50-1.12]$ & & & \\
\hline Other & $0.73[0.54-1.00]$ & & & \\
\hline
\end{tabular}

manner; however, there are limited appointments available for referrals and continued management.

\section{ART adherence rates}

Although the ART adherence rates reported in the literature are wide-ranging and dependent on the sociocultural context, there needs to be a good assessment tool to measure adherence in Latin American countries. Data reported in a meta-analysis from the United States reported the adherence rate to be $55 \%$, with good adherence deemed to be $80 \%$. When correcting this data with the $90 \%$ expectation, as is the case in this study, good adherence descends to 62\% [66]. Furthermore, studies [67] with small samples from the region report adherence rates for PLHIV as high as $90 \%$. Yet, older but slightly large studies in Peru [36] identified higher adherence rates only among people with higher education $(\mathrm{OR}=0.45 .95 \% \mathrm{CI} 0.27-0.75)$ and age $(\mathrm{OR}=1.05 .95 \%$ CI 1.02-1.08). Additional research is necessary to measure ART adherence across Peru. 
Table 4 Technical standard (NTS No. 097 MINSA/DGSP-V.02) in Peru for comprehensive care of the adult with Human Immunodeficiency Virus (HIV) infection

\author{
Any person with HIV infection who has symptoms related to immunosuppression (clinical stages 2, 3 and 4 of the WHO 2007 classification) \\ Any person with HIV infection who has a CD4T cell count $\leq 500$ cells/ $\mu \mathrm{L}$, regardless of the presence of symptoms \\ Any person with HIV infection, regardless of the presence of symptoms and CD4T cell count, who has any of the following conditions \\ HIV-related nephropathy \\ Neuro-cognitive impairment associated with HIV \\ Non-HIV neoplasms that require chemotherapy or radiation therapy \\ Coinfection with chronic hepatitis B requiring treatment \\ Chronic hepatitis $\mathrm{C}$ co-infection requiring treatment \\ HIV-related autoimmune diseases \\ Gestation \\ Anyone with acute HIV infection who has symptoms \\ Serodiscordant couples
}

Other cases, according to the criteria of the treating physician after consultation and approval of the Expert Committee on Comprehensive Care for Adults with HIV Infection

\section{Detectable viral load and ART adherence}

In an unpublished undergraduate thesis studying PLHIV in Northern Peru, ART adherence was reported to be $30 \%$, with an association identified between physical and mental quality of life and ART adherence $(\mathrm{p}=0.03$ and 0.04) [68]. Although adherence in this study was higher, almost half of the patients (45\%) had a detectable viral load. This result must be considered with caution as patients in Peru learn to obey physicians and interface with the health system with largely passive behaviours. As a result, patients who were not adherent might have decided to respond affirmatively. In addition, the detectable viral load can be partially explained by people beginning ART within the last 6 months. As 32.2\% of patients were in their first year of ART, they could still be adapting to the daily medication intake as well as the newness of any side effects. Furthermore, the inadequate incorporation of the WHO recommended ART for most participants could have limited the clinical effectiveness of treatment. The policy opportunity is to develop a regional database to monitor program outcomes, such as ART regimen, ART adherence, and level of viral resistance.

\section{Patient satisfaction and ART adherence}

The results indicate complaints about the ART regimen were a significant factor associated with non-adherence. In the metanalysis by Clay, Nag, Graham, and Narayanan [69], PLHIV taking a single pill were significantly more adherent in comparison to those taking more than one pill at any frequency (odds ratio [OR]: 2.37 [95\% CI 1.68, 3.35], $\mathrm{p}<0.001$ ), twice-daily MTR (OR: 2.53 [95\% CI 1.13, 5.66], $\mathrm{p}=0.02$ ) and the once-daily multiple tablet regimens (OR: 1.81 [95\% CI 1.15, 2.84], $\mathrm{p}=0.01$ ). Similarly, Raffi et al. [70] found significantly higher rates of ART adherence (89.6\%) among those taking a single tenofovir-emtricitabine-efavirenz therapy, compared to those taking combinations of ART $(86.4 \%>1$ pill once daily; $77.0 \%>1$ daily intake; $\mathrm{P}<0.0001$ ). As such, the policy implication is for the MINSA to consider the cost to benefit ratio for shifting ART to a one pill per day regimen.

\section{Tuberculosis comorbidity and ART adherence}

No prior evidence has been found reporting Tuberculosis (TB) comorbidity as a risk factor of ART non-adherence. However, research indicates PLHIV have a 20- to 37-fold higher risk of active TB than those without HIV [71]. The association found in this study can be explained by the summative effect of suffering from two chronic conditions, associated with stigma and discrimination, that require clinical management for an entire life. Furthermore, this study found interrupted ART at some point is a risk factor for non-adherence $(\mathrm{p}<0.001 ; \mathrm{RP}=17.17$; IC 95\%:7.19-41), more significantly for PLHIV with concurrent TB. The literature indicates ART interruptions are common, especially in the presence of other chronic conditions, due to the resulting fatigue and personal attempts to eliminate side effects with treatment [72].

\section{Study limitations}

Despite this being one of the larger studies conducted in Latin America, and the largest in Peru, this study has several limitations. First, the descriptive design with a relatively small sample size, compared to studies outside the region, was used to calculate frequencies and averages, and to perform bivariate exploratory analysis. As such, the design might not show important positive associations. However, the study sample was comprised on almost $80 \%$ of the available population in the region, so the results are at least a good approximation of the local reality. Second, access to HIV data, requires locating and 
reviewing health records in an environment with deficits in storage, limitations in standards, and inconsistencies in the organization of clinical data. This Peruvian reality can lead to errors in data collection or even missed data. Although double-checks were incorporated into this study, the possibility for errors could impact the results. Third, despite the widespread use of the instrument to calculate adherence, there are few studies that establish the positive predictive value; possibly distorting the calculated rates. However, this study included a review of the health record with a comparison to the laboratory tested viral load as a verification process. Fourth, the adherence measurement was cross-sectional; therefore, the data is limited to one moment in time versus the adherence changes over time (this was not a study objective). Fifth, the laboratory values were collected from medical records and referred to the last value recorded within the last 6 months. As such, there could be variations in lab value recorded with any pending, or misplaced, values. Despite these limitations, the resulting data was collected in a systematic and rigorous manner. Finally, despite the consecutive sampling strategy there was a low TW participation in this study. Clinicians report the TW population encounter severe stigma and pervasive discrimination in the provinces that forces them to remain "incognito" in the health system. In retrospect, a proportional quota sampling strategy might have addressed this limitation [73, 74].

\section{Conclusion}

PLHIV managed at the regional clinic in Lambayeque are mainly young men, self-identified as heterosexual, urban residents, with high school education, and lower incomes. Being co-infected with TB, having complaints about the ART regimen, and interrupting ART at some point are risk factors for non-adherence. Given the adherence rates reported in this study, the analytical values observed, and the variations in the ART management from the internationally published evidence-based standards for care of PLHIV, there are two important policy implications. First, the Peruvian national clinical practice guidelines for HIV/AIDS need to be evaluated and compared with contemporary evidence-based clinical practices and existing international standards of care. Second, the clinical practices at the regional level need to be evaluated against the national guidelines to determine the level of ART regimen compliance. These two recommendations translate into the revision of the technical standards to include current international recommendations regarding the initiation of ART and insuring the first-line medications are available to all Peruvians, not only those living in Lima.
There needs to be further research to develop strategies tailored for the Peruvian reality that achieve improvements in empowerment, self-management, and self-care that result in better ART adherence, and indirectly reduce the number of new infections. Furthermore, processes need to be implemented to increase the early diagnoses of HIV in order to improve timely treatment, reduce complications, and insure the cost-effective distribution of limited resources. This implies establishing an interdisciplinary community-based intervention to increase access to diagnostic testing for HIV in ambulatory settings versus the hospital, and to educate physicians about when and how to refer people for HIV testing.

In closing, the experience from this study needs to be translated into the development of a permanent local registry for the province where the regional clinic is located to evaluate therapeutic successes and failures. The registry should use the UNAIDS 90-90-90 targets as the primary outcome measures and then the five segments of the HIV Care Continuum to guide the construction of process measures. This can be accomplished by implementing an evidence-based interdisciplinary program, such as the Adherence Improving Self-Management. Overall, the effectiveness of HIV clinical management and pharmacological interventions need to be evaluated in order to identify the best practices and to disseminate the valuable "lessons learned" that facilitate a more effective scale-up of programs in the region.

\section{Supplementary information}

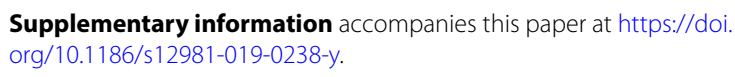

Additional file 1: Table S1. All socio-demographic characteristics of PLHIV and ART adherence at the HIV clinic (2016-2017).

\section{Acknowledgements \\ This research project was funded by a grant from Fons de Solidaritat from the Universitat Autònoma de Barcelona (Spain) and the Oficina de Investigación y Creatividad Intelectual from the Universidad María Auxiliadora (Peru). We want to thank Dr. Adrian Anast (Director of the Online Writing Center at A.T. Still University) for working with the research team to prepare this manuscript.}

\section{Disclosures}

The authors have no disclosures specific to institutional or commercial affiliations that might pose a conflict of interest regarding manuscript publication.

\section{Authors' contributions}

All authors participated in the final approval of the manuscript submitted for journal review and are accountable for ensuring that questions related to the accuracy and/or integrity of any part of the manuscript are appropriately investigated and resolved. In the addition, the following authors were involved in the: Study conception (JMLM, MFC; PAP); study design (BKLE, FELJ; JEE, JMLM, PAP); data collection (BKLE, UEEB; LYDO); data analysis (GMGV; JMLM; PAP); data interpretation (FELJ; JEE, JMLM, JRRL, MFC; PAP); drafting the manuscript (BKLE, FEL; GMGV; JRRL; MFC; UEEB; LYDO); developing the tables (GMGV); substantial revision to the manuscript (JMLM, JEE, PAP), critical revisions to the final manuscript (JMLM, PAP). All authors read and approved the final manuscript. 


\section{Funding}

This study was partially funded by a research Grant from the Fundació Autònoma Solidària (Resolució Convocatòria FSXXXIII-Peru); and the Oficina de Investigación y Creatividad Intelectual from the Universidad María Auxiliadora (OICl-001-2017)

\section{Availability of data and materials}

The majority of data collected and analyzed for this study are included in the published article and the Additional files. The complete datasets for this study are not publicly available due to the possibility for a breach of participant privacy, persons living with HIV/AIDS, in a relatively small population clinically managed at a single hospital location. However, the data will be made available to researchers, upon written request to the corresponding author, with the reason for soliciting the data.

\section{Ethics approval and consent to participate}

This study was approved by the Comité de Ética de Investigación (Research Ethics Committee) del Hospital Regional de Lambayeque (Protocol No. 0223-024-16).

\section{Consent for publication}

This consent is not applicable.

\section{Competing interests}

The authors declare that they have no competing interests.

\section{Author details}

${ }^{1}$ Departament d'Infermeria, Facultat de Medicina, Universitat Autonoma de Barcelona, Avda. Can Domenech, Building M. Office M3/211, Bellaterra (Cerdanyola del Vallès), 08193 Barcelona, Spain. ${ }^{2}$ Center for Health Sciences Research, Universidad María Auxiliadora, Av. Canto Bello 431, San Juan de Lurigancho, Lima, Lima 15408, Peru. ${ }^{3}$ Grupo de Investigación Enfermera en Vulnerabilidad y Salud (GRIVIS), Universitat Autonoma de Barcelona, Avda. Can Domenech, Building M. Office M3/211, 08193 Bellaterra (Cerdanyola del Vallès), 08193 Barcelona, Spain. ${ }^{4}$ Department of Research, Hospital Regional Lambayecue, Pro. Augusto B. Leguia Nro. 100 (Esquina con Av. Progreso N. 110-120), Chiclayo, Lambayeque 14101, Peru. ${ }^{5}$ School of Nursing, Universidad Nacional Pedro Ruiz Gallo, Av. Juan XXIII 391, Lambayeque, Chiclayo 14013, Peru. ${ }^{6}$ College of Health Sciences, Universidad Norbert Wiener, Av. Arequipa 444, Lima, Lima 15046, Peru. ${ }^{7}$ Evidence-Based Health Care South America: A Joanna Briggs Institute Affiliated Group, Universidad María Auxiliadora, Av. Canto Bello 431, San Juan de Lurigancho, Lima, Lima 15408, Peru. ${ }^{8}$ Doctor of Health Sciences Program, College of Graduate Health Studies, A. T. Still University, 800 West Jefferson Street, Kirksville, MO 63501, USA. ${ }^{9}$ Coordinator HIV/AIDS Unit, Department of Nursing, Hospital Regional Lambayeque, Pro. Augusto B. Leguía Nro. 100 (Esquina con Av. Progreso N. 110-120), Chiclayo, Lambayeque 14101, Peru. ${ }^{10}$ Center for Global Nursing, Texas Woman's University, 6700 Fannin St, Houston, TX 77030, USA. ${ }^{11}$ Midwife, Department of Obstetrics, Hospital Regional Lambayeque, Pro. Augusto B. Leguia Nro. 100 (Esquina con Av. Progreso N. 110-120), Chiclayo, Lambayeque 14101, Peru. ${ }^{12}$ Department of Medicine, Hospital Regional Lambayeque, Pro. Augusto B. Leguia Nro. 100 (Esquina con Av. Progreso N. 110-120), Chiclayo, Lambayeque 14101, Peru. ${ }^{13}$ School of Medicine, Universidad Santo Toribio Mogrovejo, Av. San Josemaría Escriva de Balaguer 855, Chiclayo, Lambayeque 14101, Peru. ${ }^{14}$ Department of Medicine, Hospital Regional Lambayeque, Lambayeque, Pro. Augusto B. Leguia Nro. 100 (Esquina con Av. Progreso N. 110-120), Chiclayo, Lambayeque 14101, Peru.

Received: 19 June 2019 Accepted: 21 August 2019

Published online: 28 August 2019

\section{References}

1. Piñeirúa A, Sierra-Madero J, Cahn P, Guevara Palmero RN, Martínez Buitrago E, Young B, Del Rio C. The HIV care continuum in Latin America: challenges and opportunities. Lancet Infect Dis. 2015;15:833-9.

2. Joint United Nations Programme on HIV/AIDS. UNAIDS data 2018. Geneva: United Nations Publishing; 2018.

3. Ministerio de Salud del Perú. En el Perú cerca de 16,250 personas viven con VIH sin saberlo. Lima: Ministerio de Salud del Perú; 2017.
4. Ortblad KF, Lozano R, Murray CJL. The burden of HIV: insights from the Global Burden of Disease Study 2010. AIDS (London, England). 2013:27:2003-17.

5. Joint United Nations Programme on HIV/AIDS. Global report on the global AIDS epidemic 2013. Geneva: WHO Press; 2013.

6. Cáceres CF, Mendoza W. The national response to the HIV/AIDS epidemic in Peru: accomplishments and gaps: a review. J Acquir Immune Defic Syndr. 2009;51:S60-6.

7. Silva-Santisteban A, Raymond HF, Salazar X, Villayzan J, Leon S, McFarland W, Caceres CF. Understanding the HIV/AIDS epidemic in transgender women of Lima, Peru: results from a sero-epidemiologic study using respondent driven sampling. AIDS Behav. 2012;16:872-81.

8. Chow JY, Konda KA, Borquez A, Caballero P, Silva-Santisteban A, Klausner JD, Cáceres CF. Peru's HIV care continuum among men who have sex with men and transgender women: opportunities to optimize treatment and prevention. Int J STD AIDS. 2016;27:1039-48.

9. Billings JD, Joseph Davey DL, Konda KA, Bristow CC, Chow J, Klausner JD, Cáceres CF. Factors associated with previously undiagnosed human immunodeficiency virus infection in a population of men who have sex with men and male-to-female transgender women in Lima, Peru. Medicine. 2016;95:e5147.

10. Beyrer C, Wirtz AL, Walker D, Johns B, Sifakis F, Baral SD. The global HIV epidemics among men who have sex with men. Washington, DC: The World Bank; 2011.

11. Ferro EG, Weikum D, Vagenas P, Copenhaver MM, Gonzales P, Peinado J, Cabello R, Lama JR, Sanchez J, Altice FL. Alcohol use disorders negatively influence antiretroviral medication adherence among men who have sex with men in Peru. AIDS Care. 2015;27:93-104.

12. Lee SW, Deiss RG, Segura ER, Clark JL, Lake JE, Konda KA, Coates TJ, Caceres CF. A cross-sectional study of low HIV testing frequency and high-risk behaviour among men who have sex with men and transgender women in Lima, Peru. BMC Public Health. 2015;15:408.

13. Global HIV \& AIDS statistics_-2019 fact sheet [https://www.unaids.org/ sites/default/files/media_asset/UNAIDS_FactSheet_en.pdf].

14. Kharsany ABM, Karim QA. HIV infection and AIDS in Sub-Saharan Africa: current status, challenges and opportunities. Open AIDS J. 2016;10:34-48.

15. De Boni R, Veloso VG, Grinsztejn B. Epidemiology of HIV in Latin America and the Caribbean. Curr Opin HIV AIDS. 2014;9:192-8.

16. Joint United Nations Programme on HIV/AIDS. Miles to go: closing gaps, breaking barriers, righting injustices. Geneva: Joint United Nations Programme on HIV/AIDS; 2018.

17. Ministerio de Salud del Perú (Ed.). Situación del VIH/SIDA en el Perú. Lima, Peru: Ministerio de Salud del Perú; 2016.

18. Centro Nacional de Epidemiología Prevención y Control de Enfermedades: Situación epidemiológica del VIH-Sida en el Perú. In Boletín VIH. Lima, Peru; 2018.

19. Joint United Nations Programme on HIV/AIDS. Prevention gap report. Geneva: United Nations Publishing; 2016.

20. Fettig J, Swaminathan M, Murrill CS, Kaplan JE. Global epidemiology of HIV. Infect Dis Clin North Am. 2014;28:323-37.

21. Dybul M, Fauci AS, Bartlett JG, Kaplan JE, Pau AK. Guidelines for using antiretroviral agents among HIV-infected adults and adolescents: the panel on clinical practices for treatment of HIV. Ann Intern Med. 2002;137:381-433.

22. Centers for Disease Control and Prevention: Monitoring selected national HIV prevention and care objectives by using HIV surveillance data_-United States and 6 dependent areas-2013. HIV Surveillance Supplemental Report 2015, 20.

23. Joint United Nations Programme on HIV/AIDS. The 2004 report on the global AIDS epidemic, vol. 4. Geneva: United Nations Publications; 2004

24. Ministerio de Salud del Perú. Norma técnica para el tratamiento antirretroviral de gran actividad - Targa en adultos infectados por el virus de la inmunodeficiencia humana. Lima: Ministerio de Salud del Perú; 2005.

25. Ministerio de Salud del Perú. Guía nacional de consejería en ITS/NIH y el SIDA. Lima: Ministerio de Salud del Perú; 2006.

26. Ministerio de Salud del Perú. Norma técnica de salud para la prevención y el control de la infección por el virus del la inmunodeficiencia humana en pueblos indígenas amazónicos, con pertinencia intercultural. Lima: Ministerio de Salud del Perú; 2016. 
27. Ministerio de Salud del Perú. Norma técnica de salud de atención integral del adulto con infección por el Virus de la Inmunodeficiencia Humana (VIH). Peru: Lima; 2014.

28. Vasquez AL, Errea RA, Hoces D, Echevarria J, González-Lagos E, Gotuzzo E. Missed opportunities for HIV control: gaps in HIV testing for partners of people living with HIV in Lima, Peru. PLOS ONE. 2017;12:e0181412.

29. Echevarría J, de Castilla DL, Seas C, Verdonck K, Gotuzzo E. Scaling-up highly active antiretroviral therapy (HAART) in Peru: problems on the horizon. J Acquir Immune Defic Syndr. 2006;43:625-6.

30. Vargas $V$. The new HIV/AIDS program in Peru: The role of prioritizing and budgeting for results. Washington, DC: World Bank Group; 2015.

31. Joint United Nations Programme on HIV/AIDS. 90-90-90-an ambitious treatment target to help end the AIDS epidemic. Geneva: United Nations Publishing; 2014.

32. Joint United Nations Programme on HIV/AIDS. UNAIDS data 2017. Geneva: United Nations Publishing; 2017.

33. Garcia-Fernandez L, Novoa R, Huaman B, Benites C. Continuo de la atención de personas que viven con $\mathrm{VIH}$ y brechas para el logro de las metas 90-90-90 en Perú. Revista Peruana de Medicina Experimental y Salud Publica. 2018;35:491-6.

34. Curioso WH, Kepka D, Cabello R, Segura P, Kurth AE. Understanding the facilitators and barriers of antiretroviral adherence in Peru: a qualitative study. BMC Public Health. 2010;10:1-8.

35. Curioso WH, Kurth AE. Access, use and perceptions regarding Internet, cell phones and PDAs as a means for health promotion for people living with HIV in Peru. BMC Med Inform Decis Mak. 2007;7:1-7.

36. Pacífico J, Guitérrez C. Información sobre la medicación y adherencia al tratamiento antirretroviral de gran actividad en pacientes con VIH/SIDA de un hospital de Lima, Perú. Revista Peruana de Medicina Experimental y Salud Publica. 2002;32:66-72.

37. Alave J, Paz J, González E, Campos M, Rodríguez M, Willig J, Echevarría J. Factores asociados a falla virológica en pacientes infectados con VIH que reciben terapia anti-retroviral en un hospital público del Perú. Revista Chilena de Infectología. 2013;30:42-8.

38. Muñoz M, Bayona J, Sanchez E, Arevalo J, Sebastian JL, Arteaga F, Guerra D, Zeladita J, Espiritu B, Wong $M$, et al. Matching social support to individual needs: a community-based intervention to improve HIV treatment adherence in a resource-poor setting. AIDS Behav. 2011;15:1454-64.

39. Tello-Velásquez JR, Díaz-Llanes BE, Mezones-Holguín E, RodríguezMorales AJ, Huamaní C, Hernández AV, Arévalo-Abanto J. La mala calidad de sueño se asocia a una menor adherencia al tratamiento antirretroviral de gran actividad en pacientes peruanos con infección por VIH/SIDA. Cadernos de Saúde Pública. 2015;31:989-1002.

40. Zafra-Tanaka JH, Ticona-Chavez E. Estigma relacionado a VIH/SIDA asociado con adherencia al tratamiento antirretroviral en pacientes de un hospital de Lima, Perú 2014. Revista Peruana de Medicina Experimental y Salud Pública. 2016:33:625-32.

41. Costa JdM. Torres TS, Coelho LE, Luz PM: adherence to antiretroviral therapy for HIV/AIDS in Latin America and the Caribbean: systematic review and meta-analysis. J Int AIDS Soc. 2018;21:e25066.

42. Mann CJ. Observational research methods. Research design II: cohort, cross sectional, and case-control studies. Emerg Med J. 2003;20:54-60.

43. Kalton G. Sampling considerations in research on HIV risk and illness. In: Ostrow DG, Kessler RC, editors. Methodological issues in AIDS behavioral research. Boston: Springer; 1993. p. 53-74.

44. Daniel J. Sampling essentials: practical guidelines for making sampling choices. California: Thousand Oaks; 2012.

45. Knobel H, Alonso J, Casado JL, Collazos J, González J, Ruiz I, Kindelan JM, Carmona A, Juega J, Ocampo A. Validation of a simplified medication adherence questionnaire in a large cohort of HIV-infected patients: the GEEMA study. AIDS. 2002;16:605-13.

46. IBM. SPSS statistics for windows. 22.0th ed. Armonk: IBM Corp; 2013.

47. Dirección Xeral de Saúde Pública da Consellería de Sanidade: EPIDAT: Epidemiological Analysis and Statistics. 3.1 edition. Coruña, España: Xunta de Galicia; 2006.

48. Massey FJ. The Kolmogorov-Smirnov Test for Goodness of Fit. J Am Stat Assoc. 1951;46:68-78

49. Landau S, Everitt BS. A handbook of statistical analyses using SPSS. 1st ed. New York: Chapman and Hall; 2003.

50. Conover WJ. Practical nonparametric statistics. 3rd ed. Wiley; 1999. ISBN13: 978-0471160687, ISBN-10: 0471160687.
51. Siegel S. Nonparametric statistics for the behavioral sciences. New York: McGraw-Hill; 1956.

52. Ho R. Handbook of univariate and multivariate data analysis and interpretation with SPSS. New York: Chapman and Hall; 2006.

53. von Elm E, Altman DG, Egger M, Pocock SJ, Gøtzsche PC, Vandenbroucke JP. The Strengthening the Reporting of Observational Studies in Epidemiology (STROBE) Statement: guidelines for reporting observational studies. Int J Surg. 2014;12:1495-9.

54. Equator Network: STROBE statement-Checklist of items that should be included in reports of cross-sectional studies. http://www.equator-netwo rk.org/reporting-guidelines/strobe/: UK EQUATOR Centre; 2018.

55. Acuña L, Fuentes JC, Soler LA, Valderrama F, Daza MT, Vaca LB, editors. Situación del VIH en Colombia 2017. Fondo Colombiano de Enfermedades: Bogotá, Colombia; 2017.

56. Rice B, Elford J, Yin Z, Croxford S, Brown A, Delpech V. Trends in HIV diagnoses, HIV care, and uptake of antiretroviral therapy among heterosexual adults in England, Wales, and Northern Ireland. Sex Transm Dis. 2014:41:257-65.

57. Centro Nacional de Epidemiología: Vigilancia epidemiológica del VIH y SIDA en España. Madrid, Spain; 2016.

58. Centers for Disease Control and Prevention. Diagnoses of HIV infection in the United States and dependent areas, 2017. HIV Surveillance Report 2018, 29.

59. Barrientos J. Situación social y legal de gays, lesbianas y personas transgénero y la discriminación contra estas poblaciones en América Latina. Sexualidad, Salud y Sociedad. 2016;22:331-54.

60. World Health Organization. Consolidated guidelines on the use of antiretroviral drugs for treating and preventing HIV infection. Recommendations for a Public Health approach. 2nd ed. Geneva: WHO Press; 2016.

61. Cohen MS, Chen YQ, McCauley M, Gamble T, Hosseinipour MC, Kumarasamy N, Hakim JG, Kumwenda J, Grinsztejn B, Pilotto JHS, et al. Prevention of HIV-1 infection with early antiretroviral therapy. N Engl J Med. 2011;365:493-505.

62. Herek G, Saha S, Burack J. Stigma and psychological distress in people with HIV/AIDS. Basic Appl Soc Psychol. 2013;35:41-54.

63. Kong MC, Nahata MC, Lacombe VA, Seiber EE, Balkrishnan R. Association between race, depression, and antiretroviral therapy adherence in a low-income population with HIV infection. J Gen Intern Med. 2012;27:1159-64.

64. Sumari-de Boer IM, Sprangers MAG, Prins JM, Nieuwkerk PT. HIV stigma and depressive symptoms are related to adherence and virological response to antiretroviral treatment among immigrant and indigenous HIV infected patients. AIDS Behav. 2012;16:1681-9.

65. Lu H-F, Hsiao F-H, Sheng W-H, Liao S-C, Wu P-Y, Yang Y-L, Chang N-T. Prevalence and predictors of depression among people living with HIV/ AIDS: a national study. Nurs Res. 2018;67:379-86.

66. Nachega JB, Mugavero MJ, Zeier M, Vitória M, Gallant JE. Treatment simplification in HIV-infected adults as a strategy to prevent toxicity, improve adherence, quality of life and decrease healthcare costs. Patient Prefer Adherence. 2011;5:357-67.

67. Hernández-Gómez AJ, Rodríguez-Ríos T, Duran-Badillo T, Vázquez-Galindo L, Gutiérrez-Sánchez G, Gracia-Castillo GN. Adherencia al tratamiento antirretroviral en pacientes con VIH/SIDA. Revista de Enfermería del Instituto Mexicano del Seguro Social. 2013;21:85-90.

68. Rivas Muro JM, Cavero Ramírez RM. Adherencia al tratamiento antirretroviral de gran actividad y calidad de vida de pacientes con $\mathrm{VIH} /$ sida del Hospital Regional Docente Las Mercedes de Chiclayo-Perú, 2011. School of Medicine: Universidad Católica Santo Toribio de Mogrovejo; 2013.

69. Clay PG, Nag S, Graham CM, Narayanan S. Meta-analysis of studies comparing single and multi-tablet fixed dose combination HIV treatment regimens. Medicine. 2015;94:e1677.

70. Raffi F, Yazdanpanah Y, Fagnani F, Laurendeau C, Lafuma A, Gourmelen J. Persistence and adherence to single-tablet regimens in HIV treatment: a cohort study from the French National Healthcare Insurance Database. J Antimicrob Chemother. 2015;70:2121-8.

71. Getahun H, Gunneberg C, Granich R, Nunn P. HIV infection-associated tuberculosis: the epidemiology and the response. Clin Infect Dis. 2010:50:S201-7.

72. Kranzer K, Ford N. Unstructured treatment interruption of antiretroviral therapy in clinical practice: a systematic review. Tropical Med Int Health. 2011:16:1297-313. 
73. Morrow KM, Vargas S, Rosen RK, Christensen AL, Salomon L, Shulman L, Barroso C, Fava JL. The utility of non-proportional quota sampling for recruiting At-risk women for microbicide research. AIDS Behav. 2007;11:586.

74. Guo Y, Li X, Fang X, Lin X, Song Y, Jiang S, Stanton B. A comparison of four sampling methods among men having sex with men in China: implications for HIV/STD surveillance and prevention. AIDS Care. 2011;23:1400-9.

\section{Publisher's Note}

Springer Nature remains neutral with regard to jurisdictional claims in published maps and institutional affiliations.
Ready to submit your research? Choose BMC and benefit from:

- fast, convenient online submission

- thorough peer review by experienced researchers in your field

- rapid publication on acceptance

- support for research data, including large and complex data types

- gold Open Access which fosters wider collaboration and increased citations

- maximum visibility for your research: over 100M website views per year

At BMC, research is always in progress.

Learn more biomedcentral.com/submissions 